\title{
THE ROLE OF SUPPRESSIVE LANGUAGE POLICIES IN LANGUAGE SHIFT AND LANGUAGE LOSS
}

\author{
Por \\ Eduardo Hernández Chávez *
}

\section{RESUMEN}

Para lograr un entendimiento del fenómeno de sustitución de lenguaje en los Estados Unidos, el autor utiliza el análisis de los derechos humanos linguísticos de Skutnabb Kangas ỳ Phillipson. El uso del español en las comunidades chicanas está siendo sustituido rápidamente por el inglés, a pesar de la gran cantidad de inmigrantes recientes que dominan el español. Este cambio va acompañado de una pérdida acelerada de la habilidad hispanoparlante. Esta sustitución linguística no depende de una decisión personal de los parlantes, sino de las condiciones sociopolíticas dentro de los Estados Unidos. Las metas políticas de lucro, explotación y hegemonía, producen políticas clasistas, racistas y etnicistas cuyo propósito es neutralizar la resistencia en contra del status quo. Esto se promueve a través de mitos seudo-liberales que justifican el lingüicismo, que trata de suprimir las culturaas minoritarias y aculturar a sus miembros para disminuir conflictos étnicos intergrupales. El continuum lingüístico de Skutnabb-Kangas y Phillipson es usado para demostrar el grado de represión lingüística que existe en algunas instituciones de Estados Unidos.

\section{ABSTRACT}

The Skutnabb-Kangas and Phillipson analysis of linguistic human rights is used as a basis for understanding language replacement phenomena in the United States. Use of Spanish in Chicano communities is shifting rapidly to English despite the huge numbers of recent immigrants who are dominant in Spanish. Accompanying this shift is a precipitous loss of proficiency by Spanish speakers. Such replacement of a language does not depend on personal choices made by speakers, but on the socio-political conditions within the country. Political goals of profits, exploitation, and hegemony drive classist, racist and ethnicist policies

\footnotetext{
* Eduardo Hemández Chávez is Assistant Professor of Linguistics at the University of New Mexico in Albuquerque and a long time activist in the Chicano community. He has written extensively in the areas of Chicano sociolinguistics, language acquisition, and philosophies of bilingual education.

Profesor asistente de lingüística en la Universidad de Nuevo México en Albuquerque. Por mucho tiempo ha sido un activista dentro de la comunidad chicana en los Estados Unidos. Ha escrito abundantemente en tópicos de sociolingüística chicana, adquisición del lenguaje y filosofía de la educación bilingüe.
} 
whose purpose is to neutralize resistance to the status quo. These are couched in liberal-sounding myths that justify linguicism, which strives to suppress minority cultures and to acculturate their members in order to pacify perceived ethnic group conflict. The Skutnabb-Kangas and Phillipson Linguicism Continuum is used to demonstrate the degree of linguistic repression in selected U.S. institutions.

\section{THE SHIFT TO ENGLISH AND THE LOSS OF SPANISH}

Within the last twenty years, the number of Spanish speakers in the U.S. has virtually tripled (Grojean, 1982), swollen in particular by the massive immigration from Mexico as well as from Central America. Yet despite the numbers and despite the extremely high proportion of first generation immigrants who are either monolingual or dominant in Spanish, there are increasingly strong indications of an inexorable shift in use toward English, the loss of Spanish facility by large numbers of third, second, and even first generation speakers, and ultimately the death of the language in scores of communities across the country.

Thus, for example, reanalyses of certain language use data that purport to show a pattern of stable diglossic bilingualism, instead demonstrate a clear shift toward the use of English (Hemández-Chávez, 1978). Similar results are reported by Veltman (1980) and by Fishman (1983), who in earlier studies had found that Spanish enjoyed a community-wide pattern of maintenance (Fishman, 1966).

Many observers, such as several of the commentors at the seminar on the Retention of Minority Language in the United States (Velman, 1980), challenge these findings. However, their objections are based largerly on unwarranted assumptions, such as the idea that the increasing presence of Spanish in commerce, the media, and other areas of public life itself signifies language maintenance. These assumptions are strongly reinforced by the belief that the growth of ethnic pride constitutes direct evidence of maintenance or that acquisition of English and loss of Spanish are unrelated to cultural assimilation.

Certainly, ethnic pride and the widespread public use of Spanish reinforce its private use and encourage transmission of the language to succeding generations. But it is a mistake to believe that language (and cultural)maintenance are processes solely internal to the ethnic community. Without fundamental changes in the

${ }^{1}$ For purpose of our discussion, shift involves changing patterns of use within a community, while native language loss refers to a range of phenomena in the individual. These include actual forgetting of at least part of a language, the cessation of leaming short of monolingual norms for the community, or deby in the acquisition of portions of the language as compared to community monolingual norms. Loss may occur for a number of reasons, but our concern here is with loss in a politico-linguistic situation. In referring to both shift and loss, we will use the term language replacement. 
deeply imbedded assimilative structures of American institutions, "maintenance" will be but a relatively shortlived phenomenon, extending mainly to the first U.S. bom generation, then being rapidly extinguished.

Few empirical studies have investigated native language loss among ethnolinguistic minorities in the U.S. either as a linguistic process or as a sociolinguistic phenomenon. Among Spanish speakers, loss has been reported almost exclusively as a concomitant of either acquisition research (Burt, Dulay and HernándezChávez, 1975) or of studies of language change processes (Ocampo, 1986; SilvaCorvalán, n.d.). Nevertheless, the anecdotal evidence within the Chicano community and the experience of teachers in the schools provide overwhelming testimony that Spanish language loss is a mayor occurrence among Chicano schoolchildren as well as adults.

Historically, Chicano children have typically entered school as Spanish-speaking monolinguals, have learned English within a year or two and, within three or four more years, have begun to show many signs of loss which persevere or even progress as they became adults. Most young immigrant children today continue to undergo a similar process. Additionally, there are now large number of children from bilingual homes whose Spanish acquisition is already arrested or delayed even before they enter school. (We note here an important effect of prior loss by the parents. The final stage is the complete failure to acquire the ancestral language).

\section{THE CONSEQUENCES OF SHIFT AND LOSS}

Shift and loss interact dynamically with each other. As children use less of their native language in second language contexts, they begin to lose facility in that language, especially in talking about those contexts. This loss, in turn, results in less use of native language until those contexts are given over to the second language.

Aside from these sociolinguistic interactions, loss and shift have important social and psycological effects on individuals and their families at the same time that they affect the cultural and social life of a community. In education, for example, the loss of native language skills prior to the adequate learning of second language can result in the condition of limited bilingualism described by SkutnabbKangas and Toukomaa (1979) with deleterious effects on cognitive-academic learning.

Even when accompanied by fairly complete learning of the second language, language loss generally carries with it strong feelings of alienation. (See Hernández-Chávez 1978, 1979, and 1985 for elaboration of these views). If members of the child's family are monolingual or highly dominant in the language 
being lost, communication between child and family members becomes strained and limited. Feeling of shame and guilt are common responses, and the child rejects his her family and its native culture. Access to and identification with an entire system of knowledge, values, and beliefs is destroyed, and the historical experience and traditions of child's own people become largely inaccesible.

Language loss, then, results in isolation of a chid from his/her community. If the child attains a relatively high level of education in the second language, a serious and far reaching social rift may develop. On one side, are the relatively uneducated speakers of the community language, and on the other, the relatively educated speakers of the dominant language. The replacement of language is almost invariably accompanied by wholesale cultural changes. The net effect is to leave the ethnic community in a socioeconomic backwater. Its native members have little education and few skills with which to develop the economic resources needed by a viable community. Its acculturated members become more directly oriented toward the majority community and their own role in it.

\section{LINGUICISM: ON THE CAUSE OF SHIFT AND THE LOSS}

Language replacement, i.e. either societal shift or individual loss within an ethnolinguistic community, occurs under conditions of contact with a majority language. However, it is by no means a necessary result of such contact. That societal bilingualism is not the culprit in replacement is evidenced by the existence of stable bilingual communities in countries all over the world where each of the language tends to be used for mostly non-overlapping purposes, and where each generation acquires full proficiency in the native language of the community.

Nor can we attribute the replacement of a minority language by a majority language to a personal choice of the speakers. Clearly, a societally dominant language will attract members of a minority group, for both instrumental and integrative reasons (Lambert, 1972). In the United States, many would like to believe that the superior utility of English and its overpowering cultural force are enough to entice speakers of minority languages not only to learn English but to willingly leave behind their outdated native tongues. But the learning of a second language does not of itself imply the loss of native language skills. Full and active bilingualism is the norm throughout the world, not the exception (Gumperz, 1971). Thus is strains credulity to believe that a normal individual would willingly and without coercion relinquish a language in which he/she learned to experience the world; a language that perfectly expresses one's ideals, codifying and organizing the elements of one's culture; $a$ lasigumg'e $t^{\text {th }}$ if forges and maintains the social bonds with family and with community. We must look for the sources of loss elsewhere.

In a recent working paper of the Roskilde (Denmark) Uni-rersitetscenter, Tove Skutnabb-Kangas and Robert Phillipson (1989) have proposed a framework for the analysis of the language rights of the ethnic minority groups in the context of 
a dominant national language. This framework, in which they develop the notion of linguicism, will prove immensely useful to the problem at hand, namely an understanding of the socio-political mechanisms that underlie language replacement, either at the societal level or in the individual.

Linguicism is defined by Skutnabb-Kangas and Phillipson (henceforth SK-P) as the "ideologies and structures which are used to legitimate, effectuate and reproduce an unequal division of power and resources... between groups that are defined on the basis of language". These ideologies and structures include some of the same political philosophies and goals that underlie racism and classism: the maintenance of privileged access to resources, the acumulation of wealth, power and maximization of profits. ${ }^{2}$

Like racism and classism, ethnicism (of which linguicism is an integral part)generates a fear that suppressed groups will demand an ever greater share of the resources that the dominant group considers its property. Thus, in the U.S. there is the perceived threat from the "Brown Tide" of Mexicans who, though they are essential to the economic health of a great many industries, are portrayed as competing for "American" jobs, sending their earnings to Mexico (though many are American Citizens and/or permanent residents), straining the welfare a deducation systems (though undocumented workers, minority groups, and poor peopleg nerally pay a totally disproportionate share of their income in taxes), andworst of all, refusing to be Americanized.

Such portrayals lead directly to ethnicist/linguicist policies and practices since the perceived threats must be neutralized. For, so long as the minority groupretains its linguistic and ethnic character, it will retain its power to resist. Therefore, it must be broken: the language and the culture of the group, as the most potent and visible realizations of ethnicity, must be eliminated through acculturation. ${ }^{4}$ Ethnic group

\footnotetext{
${ }^{2}$ In what follows, I draw heavily on SK-P's analysis and discussion. However, I have both elaborated on their ideas and put my own interpretation on them. I will therfore try to identify those ideas that are taken from SK-P's work directly and with minimal interpretation. For the rest, they are not to be found at fault. I use their term ling uicist freely and interchangeably with ethnicist since I believe that the latter more fully characterizes U.S. political philosophies though, clearly. Language suppression remains a centerpiece of the country's goals toward language minorities.

${ }^{3}$ Such fears are not always wholly imagined. Where there is inequality in the distribution of resources (land, education, jobs, political participation, etc.) minorities will often resist efforts to maintain the status quo, especially as "radicals" in their midst identify the disparities and define their consequences.

${ }^{4}$ Complete assimilation, of course, cannot be the goal, although in the U.S. it is given ample lip service. Full socio-economic integration would place members of the ethnolinguistic group into more direct competition with the majority than before and could not be allowed except in times either of great national crisis or of economic superabundance. Nevertheless, the assimilation of some individual menmers of an ethnic group is a necesary and excepted result of acculturation efforts and also serves to provide acceptable role models who will promote acculturation.
} 


\section{THE ROLE OF SUPPRESSIVE LANGUAGE POLICIES}

loyaltly must be converted into an individualized orientation toward the dominant society.

\section{LINGUICIST MYTHS}

Assimilationist policies are rarely justified directly on blatant ethnicist grounds. Instead, they are couched as a set of liberal and ostensibly reasonable assumptions and conclusions which SK-P specify in the form of six myths that are used to affirm linguicism. The first two are particularly insidious in that they acknowledge the existence of racism and the ethnicism but claim that they are problems that have either largely been overcome (Myh 1) or are a relatively minor matter of information and goodwill (Myth 2).

In support of the first myth, we may note the recent orgy of celebration by the mainstream media in this country in honor of Martin Luther King Jr.'s "I Have a Dream" speech. King joins the American Pantheon just so long as it can be proclaimed that his dream has (almost) been fulfilled. Never mind the deepening social problems in the Afro-American community and the establishment of a huge and permanent Black underclass. In the case of ethnolinguistic minorities, the first myth is confirmed by drawing favorable attention to government sponsored programs of bilingual education and to the educational gains made by linguistic minority student. ${ }^{5}$ However, one should not notice that large numbers of ethnolinguistic minority children do not participate in such programs, that the programs have a clear assimilationist focus in any case, and the educational "gains" are often measured relative to prior levels of abysmally low achievement.

Myth 2 claims that the anti-racism war -which is considered all but won-has been reduced to a few minor informational skirmishes. Linguicism or ethnicism or racism, in this view, are not systemic evils driven by entrenched political philosopies. Rather, they occur because people do not know about each other's histories, beliefs, or ways of life.

Enter cross-cultural education: the belief that teaching white students about Chicanos and Chinese and Afro-Americans -and teaching each of these groups

\footnotetext{
${ }^{5}$ In this context, it seems to have been a major strategic mistake on the part of militant linguicists to have mounted the Official English movement, despite their rather dramatic gains to date. Their campaigns in several states undermine Myth 1 and are clearly perceived as ethnicist by language minorities. As a result, resistance efforts have been strengthened and greater unity and collaboration across ethnic groups have been achieved. Perhaps most imortantly, many ethnolinguistic leadesrs have been moved to question the amount of real progress that has been made and to begin to demand programs that are less assimilationist in their goals.
} 
about the others- will produce positive feelings among the groups, create intercultural understanding, reduce tensions, and ultimately do away with racism, linguicism, etc. A major problem with this myth, of course, is that familiarity, under socio-political structures that produce inherent inequalities, not only breeds contempt all around, it exacerbates existing ethnicist attitudes as it purports to eliminate discrimiatory policies that favor the privileged majority. Students are no dummies.

Cross-cultural education does nothing to change the underlying system of inequality. It exalts the superficial culturalism of mariachis and piñatas or perhaps even of Cinco de Mayo, stripping ethnolinguistic students of the profound knowledge and participation in all aspects of their culture that are essential for them to survive as active members of their own communities. They learn instead that nonAnglo cultures, including their own, involve purely scholastic activities, meaningless in real life and equivalent to a field trip to Disneyland. What they fail to learn is that the nurturing and development of their own language and culture are the most important paths to self-realization for both themselves and their communities.

Myths 3 and 4 are important in perpetuating linguicism because with all apparent logic and reasonableness, they lay the blame for conflict and inequality on the ethnolinguistic communities themselves. Myth 3 makes the often repeated charge -seemingly supported by conflicts in places like Quebec, Nigeria, or Indiathat multilingualism or multiculturalism cause conflict. And because many multilingual countries are also poor, Myth 4 attributes poverty to multilingualism. These is no recognition of the crucial role of historical socio-political conditions in these countries, especially that of colonialism, as the ultimate causes of underdevelopment and conflict. These myths provide strong basis for the legitimization of the linguicism, since language itself is seen to be the problem. (See Nichols, 1989 for further discussion of these issues). They have the virtue also of convincing many from the ethnolinguistic community itself that multilingualism is divisive and unpatriotic.

Conversely, according to Myths 5 and 6, monolingualism and monoculturalism are the new paths to national success which should be emulated by underdeveloped countries and embraced by internal ethnolinguistic minorities. These myths ignore the singlemindedly exploitative and destructive paths that were taken in order to forge the national successes in the first place. They also fail to acknowledge that the monolingualism that they are urging on others is the monolingualism of neocolonialism. It cannot be in Swahili or Malay or even Spanish; it must be in a major European language of international commerce, ussually English. Thus we see linguicism reaching arrogantly across multiple international boundaries., threatening to monopolize and homogenize everything that it touches. 


\section{THE LINGUICISM CONTINUUM}

We have seen that the replacement of minority languages and cultures is neither a necessary consecuence of languages contact situations nor the result of a mean ingful choice by linguistic minorities themselves. Rather, shift and loss must be lain directly at the feet of fearful, exploitive, and genocidal linguicist policies. The amount and rate of replacement will depend on a number of factors, including the pervasiveness of the majority language's cultural institutions and the internal strength and cohesion of minority culture. The most crucial and determining factor, however, remains the weight of a policy's linguicist philosopies and the vigor with which they are enforced.

There are varying degrees of linguicism that are practiced in different countries around the world, from outright repression of a language to full equality. In order to describe linguicism as objectively as possible, SK-P have developed a matrix with two scales, one vertical and the other horizontal (see Figure 1). The horizontal dimension represents the nature of a given language policy or practice, with prohibition occupying the extreme left hand portion of the scale and promotion the extreme right. Toleration, non-discrimination, and permission are intermediate degrees. The vertical cimension represents the degree of explicitness of a given right, with the upper portion representing overtness and the bottom representing

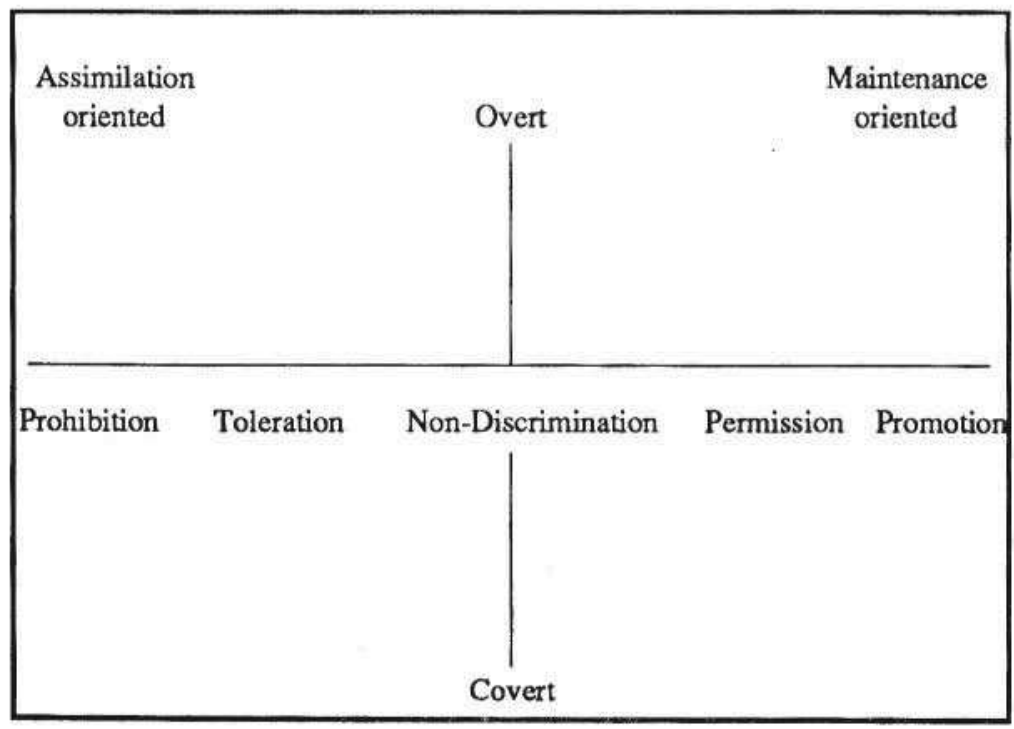

FIGURE 1. Linguicism Continuum (following Skutnabb-Kangas and Philippson, 1989). 
covertness of a given policy. In general and except for prohibition, an overt designation of a policy is to be seen as more positive than one that is covert. Thus, we may consider the degree of prohibition-promotion to be the key classification with the overtness classification as essentially a modifier.

The SK-P Linguicism Continuum will reveal, for any given language policy or practice, the degree to which it is assimilation oriented or maintenance oriented. It will thus provide useful insights into the relationship between language policies and language replacement processes. It will also permit a fairly objective comparison for two or more similar policies.

In order to ilustrate the application of the Linguicism Continuum to an understanding of language shift and language loss in the U.S., we have plotted on the scale the language policies reflected in the principal approaches to bilingual education-submersion, transitional bilingual education, structured second language immersion (the U.S. version), Canadian immersion, and developmental programs. A complete analysis on the linguicism continuum would need to include for each approach a number of variables, including language of instruction, the availability of Spanish language materials, the language of interaction with parents, program eligibility criteria, the development of the native culture, etc. We could also plot certain practices such as sanctions for speaking Spanish or the treatment of students' Spanish names. The resulting profiles would permit us to evaluate fairly specifically the degree of linguicism in any given program. For the purposes of this paper, we have simplified the procedure considerably, estimating the net effect of the different variables in order to place the program on the scale.

In addition to bilingual education, we have plotted the degree of linguicism for several other official and non-official areas of cross-linguistic interaction. These include government services as exemplified by the Department of Motor Vehicles in California, cout interpreting under both certified and uncertified conditions, Spanish language television, and commercial interactions in New Mexico.

In Figure 2, we see clearly that the submersion approach [Sub] is most linguicist, being overtly prohibitive of the native language including punishment and other sanctions. Structured immersion programs (Baker and deKanter 1983) following the initial stages [L2 Imm. (2)] are also overtly prohibitive in that they allow no Spanish. In their earlier stages, however [L2 imm. (1)], Spanish is overtly allowed for the student but not for the teacher. The use of the Spanish is progressively and firmly reduced until it is not longer allowed. Thus, we have placed this stage of the program at Overt Toleration. An essentially similar pattern presents itself for transitional bilingual education [TBE]. In the initial stages [TBE (1)], Spanish is used by students and teachers alike. At firts glance, it would seem appopiate to place it at Permission or even Promotion. However, the Spanish that is permitted is not intended to develop the language bu rather merely to keep the 
THE ROLE OF SUPPRESSIVE LANGUAGE POLICIES

\begin{tabular}{|c|c|c|c|c|}
\hline $\begin{array}{l}\text { Sub. } \\
\text { L2 Imm. }\end{array}$ & $\begin{array}{l}\text { L2 Imm. (1) } \\
\text { Dev. (2) }\end{array}$ & $\begin{array}{r}\text { Ov } \\
\text { Courts } \\
\text { DMV } \\
\text { Can. }\end{array}$ & $\begin{array}{l}\text { ert } \\
\text { (1) } \\
\text { Imm. (1) }\end{array}$ & oriented \\
\hline $\begin{array}{l}\text { Prohibition } \\
\text { TBE (2) }\end{array}$ & $\begin{array}{l}\text { Toleration } \\
\text { TBE (1) } \\
\text { Courts (2) }\end{array}$ & Non-Dis & $\begin{array}{l}\text { crimination } \\
\text { Media } \\
\text { ert }\end{array}$ & $\begin{array}{l}\text { Permission Promotior } \\
\text { Dev. (1) }\end{array}$ \\
\hline
\end{tabular}

FIGURE 2. Linguicism ratings of several types of bilingual education programs and other language rights practices.

Toward the other end of the scale, developmental programs should rate as promotion-oriented. However, taking the Carpinteria, Califomia, program as a prime exaple (Cummins, 1986), we see that it has several characteristics that preclude such a classification. First, the program is limited to the preschool. To be truly promotion oriented, a program needs to be in place throughout the grades. Its principal purpose is not maintenance but academic preparation, and it does not concern itself with cultural continuity but only individual linguistic proficiency. For these reasons, it must be placed under covert permission.

Finally the Canadian immersion programs fare very well. They begin with the native language (English in these cases) [Can. Imm. (1)] categorized as overt nondiscrimination in the early stages of the program since the teacher may not use the native language, but the student is allowed limited use of it. These programs explicitly state that the native language will not be prejudiced, so at least in this sense they are significantly different from U.S. structured immersion proposals. The Canadian programs move to overt promotion in the later elementary years [Can. Imm. (2)] explicitly developing the native language to its fullest alongside the second language.

Other official language policies fare little better than bilingual education. Most states now have policies requiring a court interpreter for non-English speaking clients. This policies most often are implemented at the discretion of a judge and 
may or may not require certification of the interpreter. There is usually no attempt to insure that the client comprehends what is going on in the courtroom, only to have his/her own testimony translated to the court. At best this can be placed at overt non-discrimination [Court (1)]. In some jurisdictions, an official interpreter is not used. Rather, an employee and often even an arresting officer who speaks the language of a defendant is called upon to interpret. These situations are rated as covert toleration.

In California, many motor vehicle regulations and procedures are written in Spanish and are freely avalilable. Interactions at DMV offices, however, are almost always in English unless there happens to be a Spanish-speaking employee on thepremises who is not otherwise occupied. We have placed this situation as overt non-discrimination.

Finally, Spanish language electronic media are fairly freely permitted across the country, but they only have been able to acquire very limited markets. Most of the television stations, even in New Mexico, are controlled by non-local interest and are almost totally unconcerned with community language and cultural maintenance. The programming is imitative of American commercial TV, the local culture is ignored (there are no public service type programs in Spanish), and the varieties of language are always standard non-Chicano Spanish. We may best place such a situation as covert non-discrimination, though somewhat toward permission.

\section{CONCLUSION}

This illustrative application of the Linguicism Continuum provides a rather interesting glimpse at a typical slice of language policy in U.S. institutions. We see that, by and large, they tend toward the prohibition and toleration end of the scale. This should not surprise us given the semi-official notion of the "melting pot" and the historical myths that are widely disseminated by the schools, the media, and the government itself. The U.S. has historically dealt with its non-white, and even some white, minorities with linguistic and cultural repression, including slaughter and enslavement. In this more enlightened age, more subtle but equally effective ethnicist strategies are used, the purpose of which is to neutralize ethnic resistance to policies of inequality. What better way than to proclaim equality a fact, dependent only on relinquishing one's identity and accepting individual responsability for success through American culture and the English language. Even were it truly possible, even if these were no racism, no classism, no ethnicism, the cost would be cultural genocide.

That price is too high. We are reminded of this by the poignant word of the narrator of a dramatic performance of some New Mexican Cuentos: ${ }^{6}$

'You Say Chaquegüe and I Say Shaquegüe by Mónica V. Sánchez and Marcos Martínez, 1989. Based on Cuentos Españoles de Colorado y Nuevo México by Juan B. Rael. 


\section{THE ROLE OF SUPPRESSIVE LANGUAGE POLICIES}

En aquel entonces, cuando me imaginaba como abuela Nunca pensé que nietos míos no iban a poder hablarme Pero ellos no hablan el mexicano, y aunque entiendo el inglés, no entienden mi "acento"

Bueno, no le hace.

Aunque compartiéramos un idioma

Siempre están too busy, watching the T.V.

Me puse a recordar cada palabra

Cada detalle de los mundos

Que crearon mis abuelos

Porque quería eternizar la misma

Tradición, Vida, Comunidad, Amor, Magia...

\section{REFERENCES}

BAKER, Keith and Adrianne de Kanter. 1981. Effectiveness of Bilingual Education: A Review of the Literature. Washington, D.C.: Ofice of Planning, Budget, and Evaluation.

BURT, Marina, Heidi Dulay and Eduardo Hernández-Chávez. 1975. Bilingual Syntax Measure: Technical Handbook. New York: Harcourt Brace Jovanovich.

CUMMINS, Jim. 1986. "Empowering Minority Students: A Framework for Intervention". Harvard Education Review, 56:1.

FISHMAN, Joshua and John Hofman. 1966. "Mother Tongue and Nativity in the American Population". In: Joshua Fishman et al. (eds.), Language Loyalty in the United States. The Hague: Mouton.

FISHMAN, Joshua and William Milán. 1983. "Spanish Language Resources of the United States: Some Preliminary Findings". In: Lucía Elías Olivares (ed.) Spanish in the US. Setting: Beyond the Southwest, Washington, D. C.: National Clearinghouse for Bilingual Education.

GROJEAN, Francois. 1982. Life with TwoLanguages: An Introduction to Bilingualism. Cambridge, MA: Harvard University Press.

GUMPERZ, John J. 1971. "Types of Linguistic Communities". In: Anewar S. Dil (ed.,) Language in Social Groups: Essays by John Gumperz. Stanford: Stanford University Press.

HERNANDEZ-Chávez, Eduardo. 1978. "Language Maintenance, Bilingual Education, and Philosophies of Bilingualism in the United States". In James E. Alatis (ed.) International Dimensions of Bilingual Education. Georgetown University, Roundtable on Languages and Linguistics 1978. Washington D. C.: Georgetown University School of Languages and Linguistics. 
- 1979. "Meaningful Bilingual Education: A Fairlytale". In: Eugene Briére (ed.) Language Development in Bilingual Setting. Pomona, CA.: National Multilingual Materials Development Center.

- 1985. "The Inadequacy of English Immersion Education as an Educational Approach for Language Minority Students in the United States". In: Office of Bilingual Education, Studies on Immersion Education: A Collection for United States Educators. Sacramento: California State Departament of Education.

LAMBERT, Wallace E. 1972. "Evaluation Reactions to Spoken Languages". In: Anwar S. Dil (ed.) Language, Psychology, and Culture: Essays by Wallace E. Lambert. Stanford: Stanford University Press.

NICHOLS, Steven. 1989. The Official English Movement in the United States (with special reference to New Mexico and Arizona). University of New Mexico, M.A. Thesis.

OCAMPO, Francisco. 1986. "El subjuntivo en tres generaciones de hablantes bilingles." Paper presented at the "Español en los Estados Unidos" VII Conference, Albuquerque, New Mexico.

SILVIA-Corvalan, Carmen. N.d. Past and Present Perspectives on Language Change in U.S. Spanish. Mimeo, University of Southem California.

SKUTNABB-Kangas, Tove and Perti Toukomaa. 1979. "Semilingualism and Middle Class bias: A Reply to Cora Brent-Palmer." Working Papers on Bilingualism 19. Toronto: Modem Language Centre, Ontario Institute for Studies in Education.

SKUTNABB-Kangas, and Robert Phillipson. 1989. Wanted: Linguistic Human Rights. Roling Papir 44-89, Roskilde Universitets Center Lingvistgruppen.

VELTAN, Calvin. 1980. The Retention of Minority Languages in the United States: A Seminar on the Analytical Work of Calvin J. Veltman. Washington, D. C.: National Center for Education Statistics. 